\title{
High Sequence Variability Among Little cherry virus Isolates Occurring in British Columbia
}

J. Theilmann, S. Orban, and D. Rochon, Agriculture and Agri-Food Canada, Pacific Agri-Food Research Centre, 4200 Highway 97, Summerland, British Columbia V0H 1Z0

\begin{abstract}
Theilmann, J., Orban, S., and Rochon, D. 2004. High sequence variability among Little cherry virus isolates occurring in British Columbia. Plant Dis. 88:1092-1098.

The LC5 isolate of Little cherry virus (LChV-LC5) is one of at least two distinct viruses contributing to a severe disease of cherry (Little cherry disease [LChD]) in British Columbia. A nearcomplete nucleotide sequence of LChV-LC5 is available as well as polyclonal antibodies against LChV-LC5 coat protein produced in bacterial cells. A survey for LChV-LC5-infected trees in the Okanagan Valley and Kootenay region of British Columbia was carried out using enzymelinked immunosorbent assays (ELISA) and LChV-LC5 antibodies. Reverse transcriptase polymerase chain reaction (RT-PCR) and sequence analysis of four different regions of the genomes of 31 of these isolates have been conducted. A high level of sequence variability was found: nucleotide sequence divergence between LChV-LC5 and the other sequenced isolates ranged from 0 to $19.7 \%$, and amino acid sequence divergence ranged from 0 to $9.1 \%$. Further examination of RT-PCR and sequence data identified six discrete groups of isolates, including a group identical to LChV-LC5. The high level of divergence in LChV-LC5 isolates occurring in British Columbia suggests that caution should be used in the selection of methods used for diagnosis during surveys for this virus.
\end{abstract}

Little cherry disease (LChD) occurs worldwide in several cultivars of sweet cherry and results in small, misshapen fruit with poor color. In some varieties of cherry trees, red or bronzing of the leaf surface is observed in late summer or fall (18). Cherries of diseased trees also fail to develop significant sweetness and acidity, rendering cherries unmarketable (19). LChD was first identified in 1933 in the Kootenay Valley of British Columbia $(7,16)$. The disease spread quickly, spreading to all orchards and to all trees within an orchard, and by 1979 production had declined by $90 \%$. LChD remains a threat to the cherry industry in British Columbia (4,9,13), and measures are in place to control the spread of the virus.

Several studies indicate the involvement of a mealybug-transmitted virus in $\mathrm{LChD}$ $(2,12)$. A virus associated with $\mathrm{LChD}$ in British Columbia (LChV-LC5) has been almost entirely cloned and sequenced $(3,17)$. Amino acid sequence comparisons indicate that LChV-LC5 is a member of the Ampelovirus genus in the family Clos-

Corresponding author: D. Rochon

E-mail: rochonda@agr.gc.ca

AAFC Contribution no. 2159.

Accepted for publication 27 May 2004.

Publication no. D-2004-0813-01R

(C) 2004 Department of Agriculture and AgriFood, Government of Canada, Minister of Public Works and Government Services Canada teroviridae and is most closely related to other mealybug-transmitted ampeloviruses. Sequences of two other members of the Closteroviridae, also associated with $\mathrm{LChD}$, Little cherry virus 1 (LChV-1, 8) and Little cherry virus 2 (LChV-2, 14), have also been reported. Comparisons indicate that $\mathrm{LChV}-1$, a virus initially isolated and sequenced in Germany (8), is only distantly related to the second $\mathrm{LChV}$ isolated in Germany from trees initially imported from the United States. This second virus was designated LChV-2 (14). A Canadian isolate (LChV-LC5, 3) was shown to have $97.8 \%$ similarity within an approximate $0.5-\mathrm{kb}$ region of the RdRp of LChV-2 (14). A comparison of the LC5 isolate with the database entry for the LChV-2 isolate indicated nucleotide sequence overlap between these two partial sequences in an approximate 4.7-kb region that encompasses the HEL and RdRp regions. Sequence comparisons within this region showed that the LC5 isolate shares $77 \%$ overall nucleotide sequence identity to LChV-2. A high percentage of nucleotide sequence identity was found in the HEL (93\%) and RdRp (94\%) encoding regions of $\mathrm{LChV}-2$. However, the $2.5-\mathrm{kb}$ region upstream of the HEL and RdRp regions showed only $68 \%$ sequence identity. Based on the overall $77 \%$ nucleotide sequence identity in the $4.7-\mathrm{kb}$ region, LChV-LC5 was tentatively suggested to be a separate species, designated LChV-3 (17).

Subsequent sequencing studies in Germany indicate that the tree infected with the originally described $\mathrm{LChV}-2$ genome contained an additional distinct genome, designated LChV-2(USA6b) (15). Sequence analysis of LChV-2(USA6b) indicates a much closer relationship to the Canadian LC5 isolate, with approximately 93\% overall sequence identity. For continuity with the literature, and until the taxonomy of LChV isolates are decided, we will reference LChV-3 isolates as LChVLC5 $(2,3,17)$.

An enzyme-linked immunosorbent assay (ELISA)-based test for LChV-LC5 has been developed using antibodies raised against bacterially expressed p39 coat protein of LChV-LC5 (17). The ELISA is being assessed for its utility in diagnosing LChV-LC5 infection in cherry trees in the major fruit growing regions of British Columbia. A preliminary survey conducted during the 2000 growing season detected LChV-LC5 in 102 of 935 trees tested $(13,17)$. All of the trees testing positive showed fruit symptoms typical of LChD. However, some trees giving a positive ELISA did not give a positive reaction when further tested using a previously developed reverse transcriptase polymerase chain reaction (RT-PCR) test developed using LChV-LC5 sequence corresponding to a portion of the $\operatorname{RdRp}(3)$. Variability in viral genomes is a well-known phenomenon, particularly among the closteroviruses (10). The known heterogeneity of closteroviruses along with the anomalous ELISA/ RT-PCR results with some cherry trees displaying $\mathrm{LChD}$ symptoms prompted us to examine if heterogeneity occurs among some LChV-LC5 isolates occurring in British Columbia.

\section{MATERIALS AND METHODS}

Virus samples. All samples described in this study were obtained from leaves of cherry trees collected during a survey for LChV-LC5 infection in the major fruit growing regions of British Columbia (17). The origin of LChV-LC5 was as described previously (referred to as $\mathrm{LChV}-3$ in reference 17).

RT-PCR. Total RNA was extracted from cherry leaves using Qiagen RNeasy columns (Qiagen Canada, Mississauga, Ontario). Approximately $0.5 \mathrm{~g}$ of leaf tissue was torn from a group of 10 leaves collected from different branches of one tree. Purified RNA was used in the RT-PCR reactions using the five primer sets described in Table 1. First-strand cDNA was 
synthesized using SuperScript II (Invitrogen, Burlington, Ontario) according to the manufacturer's recommendations. The reverse primers used for this reaction are listed in Table 1. One $\mu \mathrm{l}$ of the reverse transcription product was then used in a 25- $\mu$ PCR reaction to amplify each region of interest (Table 1). PCR was conducted in $1.5 \mathrm{mM} \mathrm{MgCl} 2,0.125 \mathrm{mM}$ each dNTP, $0.5 \mu \mathrm{M}$ each primer using 2.5 units Taq polymerase (Invitrogen). The mix was subjected to the following amplification profile: one cycle at $94^{\circ} \mathrm{C}$ for $1 \mathrm{~min} ; 30$ cycles at $94^{\circ} \mathrm{C}$ for $30 \mathrm{~s}, 42$ to $48^{\circ} \mathrm{C}$ (depending on the primer set) for $30 \mathrm{~s}, 72^{\circ} \mathrm{C}$ for $1 \mathrm{~min}$; and one cycle at $72^{\circ} \mathrm{C}$ for 10 min. Ten $\mu$ l of the $25-\mu$ l PCR reaction was subjected to agarose gel electrophoresis to determine if a product was present.

Sequencing of RT-PCR products. Sequencing was conducted on an aliquot of DNA from the combined PCR products of six identical reactions. PCR products were purified from $1 \%$ agarose gels using QIAEX II (Qiagen Canada). Cycle sequencing, using dye-labeled terminators and AmpliTaq polymerase, FS (Perkin-Elmer, Mississauga, Ontario), was conducted using an ABI PRISM 310 Genetic Analyzer.
Sequence analysis. Sequences were aligned using Geneworks (Intelligenetics, Inc., Mountain View, CA) or ClustalW. Generation of dendrograms for phylogenetic analysis was as follows. Aligned sequences were subjected to resampling using the Bootstrap method (5) and 100 replicates. A consensus phylogenetic tree was obtained using a Web-based version of the program Phylip (Web-Phylip) originally described by Felsenstein (Phylip 3.2 manual, University of California Herbarium, Berkeley) and available on the Internet through the Canadian Bioinformatics Resource. The Fitch-Margoliash (6) method was used to construct the phylogenies.

\section{RESULTS AND DISCUSSION}

Sequence comparisons of several isolates of LChV-LC5 with the previously described LChV-LC5 sequence. Thirtyone samples of cherry leaf material that gave a positive reaction in ELISA using LChV-LC5 p39 coat protein (CP) antisera during a survey for LChV-LC5 in British Columbia were further analyzed by RTPCR and sequence analysis (17). Seventeen of the samples were from Penticton in the Okanagan Valley of British Columbia, and 14 of the samples were from Creston in the Kootenay region of British Columbia. RT-PCR was conducted using primers to two regions in the ORF for the $\mathrm{LChV}$ LC5 RNA dependent RNA polymerase (RdRp1, 409 nucleotides; RdRp2, 327 nucleotides), a single region in the HSP70 homologue (HSP70, 615 nucleotides), to the CP (1,082 nucleotides) and to a truncated region of the coat protein (CPtr, 291 nucleotides) that is conserved among closterovirus CPs (Table 1 and Fig. 1). All primers were designed based on the previously sequenced LChV-LC5 genome (17). Table 2 summarizes the results of the RTPCR analysis. It can be seen that not all primer sets gave RT-PCR products for every isolate. For example, primer set RdRp1 amplified a 409 nucleotide fragment in all samples from the Okanagan and five samples from the Kootenay region but failed to give a product in the remaining nine isolates, all from the Kootenay region. Primer sets RdRp2 and HSP70 were similar to primer set RdRp1 in yielding reaction products to all isolates from the Okanagan and the same five isolates from the Kootenay region, but an addi-

Table 1. Primer pairs used for amplifying portions of the genomes of the LC5 isolate of Little cherry virus (LChV-LC5)

\begin{tabular}{|c|c|c|c|c|c|c|}
\hline $\begin{array}{l}\text { Primer } \\
\text { name }\end{array}$ & Polarity & $\begin{array}{c}\text { Annealing } \\
\text { temp }^{\mathrm{a}}\end{array}$ & Primer sequence $\left(5^{\prime}-3^{\prime}\right)$ & $\begin{array}{c}\text { LChV-LC5 } \\
\text { region }^{\mathrm{b}}\end{array}$ & $\begin{array}{l}\text { Genome location of } \\
\text { RT-PCR product }\end{array}$ & $\begin{array}{c}\text { Genome location of } \\
\text { sequenced area }^{\mathrm{d}}\end{array}$ \\
\hline PLC26L $\mathrm{L}^{\mathrm{e}}$ & Forward & $42^{\circ} \mathrm{C}$ & GCAGTACGTTCGATAAGAG & $R d R p 1^{f}$ & $4288-4696(409 \mathrm{nt})$ & $4307-4677$ (371 nt) \\
\hline PLC26R & Reverse & & AACCACTTGATAGTGTCCT & & & \\
\hline A101 & Forward & $44^{\circ} \mathrm{C}$ & TTACCATCGGAGTTCTGTG & $\operatorname{RdRp} 2^{\mathrm{f}}$ & $3980-4306$ (327 nt) & $4002-4287$ (286 nt) \\
\hline A102 & Reverse & & CTCTTATCGAACGTACTGC & & & \\
\hline A72 & Forward & $48^{\circ} \mathrm{C}$ & TTGGTACTACCTTTTCAACAGCCG & $\mathrm{HSP}^{\mathrm{f}}$ & $7195-7809$ (615 nt) & 7219-7782 (564 nt) \\
\hline A73 & Reverse & & CGAAAGTCCCACCACCAAAATCG & & & \\
\hline A99 & Forward & $44^{\circ} \mathrm{C}$ & CGGTCAAGTTTTGGTGATGG & $\mathrm{CP} \operatorname{tr}^{\mathrm{f}}$ & $11541-11831$ (291 nt) & $11579-11810(232 \mathrm{nt})$ \\
\hline A100 & Reverse & & CCATCAACCACATAAGGATAG & & & \\
\hline A59 & Forward & $44^{\circ} \mathrm{C}$ & АCCATGGCAGATTCATCTATAACG & $\mathrm{CP}^{\mathrm{f}}$ & 10912-11994 (1082 nt) & $N A^{h}$ \\
\hline TC3 & Reverse & & GCAAAGCTTGACTCАТААТТTCТСАА & $\mathrm{CT}^{\mathrm{g}}$ & & \\
\hline
\end{tabular}

${ }^{a}$ Refers to annealing temperature used in polymerase chain reaction (PCR).

${ }^{\mathrm{b}}$ Refers to LChV-LC5 5 protein coding region to which primers were made and corresponds to nomenclature used in Figure 1.

${ }^{\mathrm{c}}$ Refers to the location in the LChV-LC5 genome that primer pairs correspond to (17). Numbers in parentheses indicate length of the reverse transcriptase (RT)-PCR product.

${ }^{d}$ Refers to genome location of sequenced region of the RT-PCR product. Numbers in parentheses indicate the length in nucleotides of the RT-PCR product that was sequenced.

e Primer sequences are the same as those of Eastwell and Bernardy (3).

${ }^{\mathrm{f}}$ Regions: RdRp $=$ RNA dependent RNA polymerase; HSP70 $=$ heat shock protein 70 homologue CPtr $=$ truncated region of coat protein; $\mathrm{CP}=$ coat protein.

$\mathrm{g}$ Nucleotides in italics were used for cloning purposes and are not part of the LChV-3 genome.

${ }^{\mathrm{h}}$ Region not sequenced in any of the isolates (RT-PCR data only).

$\stackrel{2}{1} \stackrel{4}{\perp} \quad \stackrel{6}{\perp} \quad \stackrel{8}{1} \quad \stackrel{10}{\perp} \mathrm{kb}$

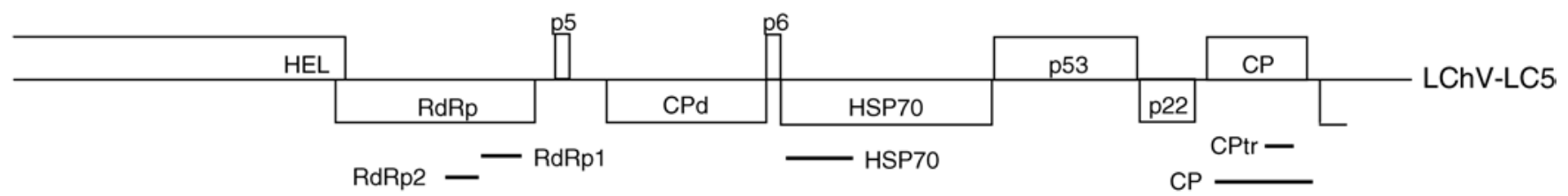

Fig. 1. Location of reverse transcriptase polymerase chain reaction (RT-PCR) amplified regions on the genome of the LC5 isolate of Little cherry virus (LChV-LC5). The LChV-LC5 genome organization is shown along with the location of the regions amplified by RT-PCR. See Table 1 for nucleotide positions of each oligonucleotide primer pair used in the RT-PCR reaction. Abbreviations of open reading frames: HEL $=$ helicase; RdRp $=$ RNA dependent RNA polymerase $; \mathrm{CPd}=$ coat protein duplicate; $\mathrm{HSP} 70=$ heat shock protein 70 homologue; $\mathrm{CP}=$ coat protein; $\mathrm{p} 5$, $\mathrm{p} 6$, $\mathrm{p} 53$, and $\mathrm{p} 22$ are unknown proteins . 
tional two isolates from the Kootenay region also gave a positive reaction. The primers for the complete $\mathrm{CP}$ only gave positive reactions to seven of the Okanagan isolates and five of the Kootenay isolates (the same isolates that reacted with each of the primer sets for RdRp1, RdRp2, and HSP70). Primers to $\mathrm{CPtr}$, which were prepared to a conserved region of the closterovirus coat protein, gave reaction products to all 31 isolates. The differential reactivity of the primer sets to the various isolates suggested that perhaps some variability of the nucleotide sequences of LChV-LC5 isolates occurs within the surveyed area.

Sequence analysis of portions of the RTPCR products of several LChV-LC5 isolates was then conducted to look at the level of variability among the isolates and their extent of similarity or dissimilarity to the corresponding regions in the previously sequenced LChV-LC5. Figure 2 shows an alignment of the nucleotide sequence of the CPtr region of all 31 isolates. A very high level of divergence among the isolates can be seen, wherein, in all, 55 of 232 nucleotide positions $(23.7 \%)$ are variable when compared with LChV-LC5. The majority of the variability is due to variation in isolates 333 and 346. Another noteworthy aspect of the data shown in Figure 2 (and Table 2) is that two or more isolates can be grouped together based on the specific nucleotide changes that occur in comparison to LChV-LC5. For example, sequences of the CPtr regions of isolates $88,128,133,136,494,496,502,510$, and 517 are identical to each other in the overlapping sequenced regions (isolate 55 is identical in all but one nucleotide residue), and the group as a whole has 11 conserved nucleotide changes relative to LChV-LC5 (hereafter referred to as group OK-2). Similarly, isolates 317, 318, 321, 369, 371,372 , and 374 are all identical to each other in the overlapping sequenced regions, and the group shows 10 conserved nucleotide changes in $\mathrm{CPtr}$ in comparison with LChV-LC5 (group K-3; Table 2 and Fig. 2). Similar findings were made for groups $\mathrm{K}-4, \mathrm{~K}-5$, and $\mathrm{K}-6$, which contain two, two, and three members, respectively, and have 40, six, and two conserved changes relative to LChV-LC5. The average percent sequence divergence in the CPtr region among these six groups is summarized in Table 3.
When the sequences of other genome regions were compared, findings similar to those in the analyses of the CPtr were found. For example, an alignment of the sequenced portions of the HSP70 regions of isolates 86, 55, 494, 517, 333, and 346 shows that the isolates fall into groups based on $100 \%$ or near $100 \%$ sequence identity among the members of the group (Fig. 3). In addition, the isolates group in the same way that they grouped when CPtr sequences were compared. Thus, the HSP70 region of isolate 86 is identical to LChV-LC5 and therefore groups with LChV-LC5 in group OK-1. Isolates 55, 494, and 517, which show 36 conserved substitutions relative to $\mathrm{LChV}-\mathrm{LC} 5$, group together (group OK-2); and isolates 333 and 346, which have 111 substitutions, group together (K-4). The HSP70 regions of isolates 332 and 343 are distinct from each other and therefore constitute two separate groups as they did when the sequences of the CPtr regions were compared. Figure 4 shows a comparison of the sequenced portions of the RdRp1 and RdRp2 regions of several isolates, showing again that individual isolates group together in the same way they do for the

Table 2. Reverse transcriptase polymerase chain reaction (RT-PCR) analysis of several Little cherry virus LC5 $^{\text {isolates in five amplified regions }}{ }^{\mathrm{a}}$ of the genome ${ }^{\mathrm{b}}$

\begin{tabular}{|c|c|c|c|c|c|c|}
\hline $\begin{array}{l}\text { Location/ } \\
\text { Isolate name }\end{array}$ & RdRp1 (409 nt) & RdRp2 (327 nt) & HSP70 (615 nt) & CP (1082 nt) & CPtr (291 nt) & Group $^{d}$ \\
\hline \multicolumn{7}{|l|}{ Okanagan } \\
\hline 86 & $+(\mathrm{S})^{\mathrm{e}}$ & $+(\mathrm{S})$ & $+(\mathrm{S})$ & + & $+(\mathrm{S})$ & OK-1 \\
\hline 12 & $+(S)$ & + & + & + & $+(\mathrm{S})$ & OK-1 \\
\hline 15 & + & + & + & + & $+(\mathrm{S})$ & OK-1 \\
\hline 16 & + & + & + & + & $+(\mathrm{S})$ & OK-1 \\
\hline 19 & + & + & + & + & $+(\mathrm{S})$ & OK-1 \\
\hline 94 & + & + & + & + & $+(\mathrm{S})$ & OK-1 \\
\hline 560 & $+(\mathrm{S})$ & + & + & + & $+(\mathrm{S})$ & OK-1 \\
\hline 55 & $+(\mathrm{S})$ & $+(\mathrm{S})$ & $+(\mathrm{S})$ & - & $+(\mathrm{S})$ & OK-2 \\
\hline 88 & + & + & + & - & $+(\mathrm{S})$ & OK-2 \\
\hline 128 & + & + & + & - & $+(\mathrm{S})$ & OK-2 \\
\hline 133 & $+(\mathrm{S})$ & + & + & - & $+(\mathrm{S})$ & OK-2 \\
\hline 136 & + & + & + & - & $+(\mathrm{S})$ & OK-2 \\
\hline 494 & $+(\mathrm{S})$ & $+(\mathrm{S})$ & $+(\mathrm{S})$ & - & $+(\mathrm{S})$ & OK-2 \\
\hline 496 & $+(\mathrm{S})$ & + & + & - & $+(\mathrm{S})$ & OK-2 \\
\hline 502 & + & + & + & - & $+(\mathrm{S})$ & OK-2 \\
\hline 510 & + & + & + & - & $+(\mathrm{S})$ & OK-2 \\
\hline 517 & + & $+(\mathrm{S})$ & $+(\mathrm{S})$ & - & $+(\mathrm{S})$ & OK-2 \\
\hline \multicolumn{7}{|l|}{ Kootenay } \\
\hline 317 & - & - & - & - & $+(\mathrm{S})$ & $\mathrm{K}-3$ \\
\hline 318 & - & - & - & - & $+(\mathrm{S})$ & $\mathrm{K}-3$ \\
\hline 321 & - & - & - & - & $+(\mathrm{S})$ & K-3 \\
\hline 369 & - & - & - & - & $+(\mathrm{S})$ & $\mathrm{K}-3$ \\
\hline 371 & - & - & - & - & $+(\mathrm{S})$ & K-3 \\
\hline 372 & - & - & - & - & $+(\mathrm{S})$ & $\mathrm{K}-3$ \\
\hline 374 & - & - & - & - & $+(\mathrm{S})$ & $\mathrm{K}-3$ \\
\hline 333 & - & $+(\mathrm{S})$ & $+(\mathrm{S})$ & - & $+(\mathrm{S})$ & $\mathrm{K}-4$ \\
\hline 346 & - & $+(\mathrm{S})$ & $+(\mathrm{S})$ & - & $+(\mathrm{S})$ & $\mathrm{K}-4$ \\
\hline 331 & + & + & + & + & $+(\mathrm{S})$ & K-5 \\
\hline 332 & $+(\mathrm{S})$ & $+(\mathrm{S})$ & $+(\mathrm{S})$ & + & $+(\mathrm{S})$ & K-5 \\
\hline 299 & + & + & + & + & $+(\mathrm{S})$ & K-6 \\
\hline 322 & + & + & + & + & $+(\mathrm{S})$ & K-6 \\
\hline 343 & $+(\mathrm{S})$ & $+(\mathrm{S})$ & $+(\mathrm{S})$ & + & $+(\mathrm{S})$ & K-6 \\
\hline
\end{tabular}

${ }^{a}$ Regions: RdRp = RNA dependent RNA polymerase; HSP70 = heat shock protein 70 homologue; $\mathrm{CP}=$ coat protein; $\mathrm{CPtr}=$ truncated coat protein region.

${ }^{\mathrm{b}}$ Positive RT-PCR reactions are indicated by the + symbol and negative reactions by the - symbol.

${ }^{\mathrm{c}}$ Numbers in parentheses refer to the size of the RT-PCR product obtained in positive reactions.

${ }^{\mathrm{d}}$ Refers to the groupings based on sequence analyses.

e Indicates that RT-PCR product was sequenced. 
HSP70 and CPtr regions. A summary of the percent nucleotide sequence divergence in the four amplified regions of all six groups of LChV-LC5 isolates is shown in Table 3.
Table 3 shows that average sequence divergence from LChV-LC5 in the four sequenced portions of the six groups ranges between 0 and $19.7 \%$. The highest level of divergence occurred in group K-4 in the
HSP70 region. Group K-4 also showed high levels of divergence in the RdRp2 $(14.3 \%)$ and CPtr regions (17.2\%). The high level of sequence divergence in these isolates may explain the inability to obtain
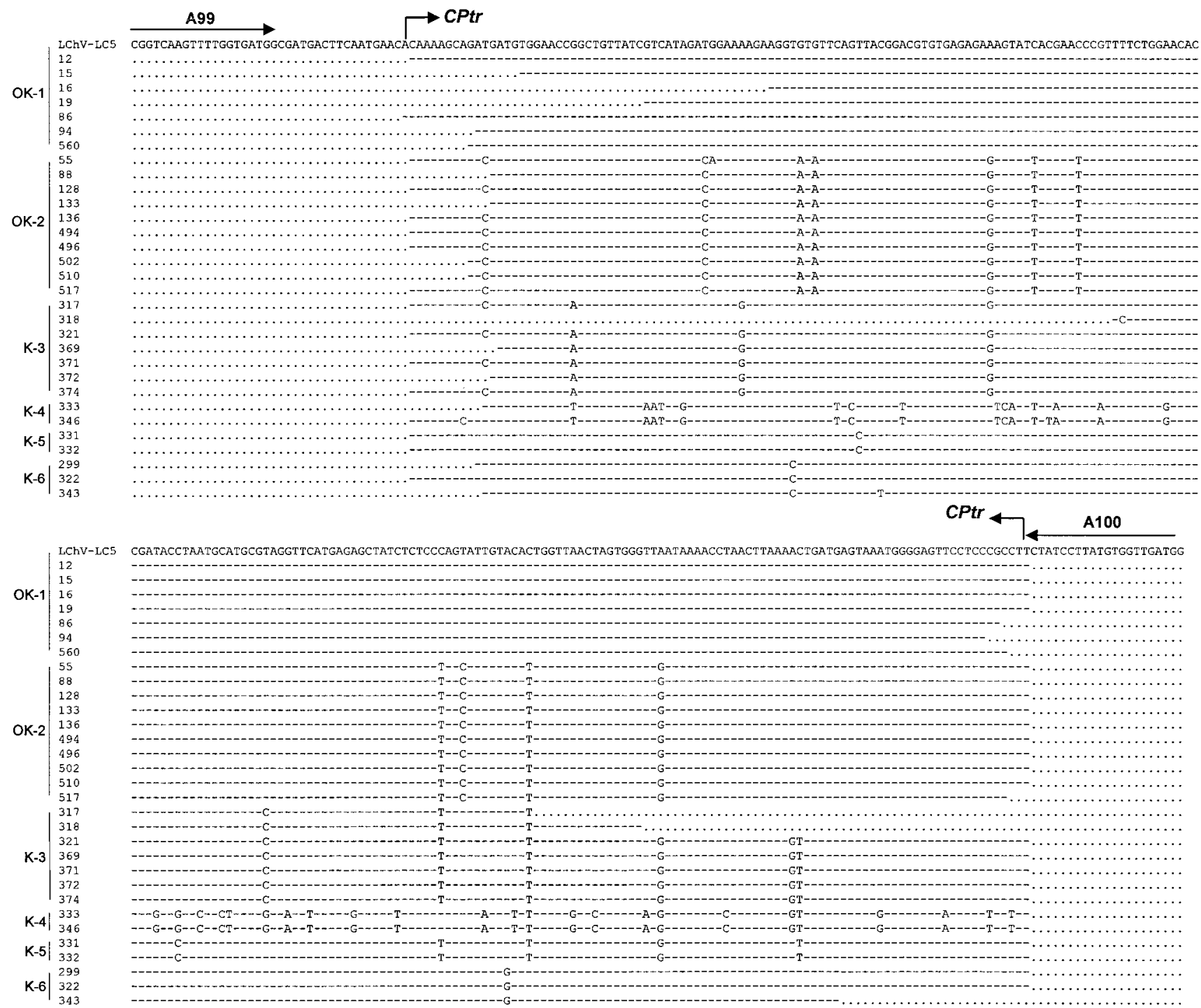

Fig. 2. Nucleotide sequence comparison of a truncated portion of the coat protein (CPtr) open reading frame of several isolates of Little cherry virus LC5 (LChV-LC5). A portion of the CPtr region of the $31 \mathrm{LChV-LC5}$ isolates were sequenced and aligned. Locations of primers (see Table 1) are indicated by forward and reverse arrows. A bent arrow shows the beginning of the region used in sequence comparisons. Dots correspond to regions for which sequence data were not obtained. Only nucleotides that differ from the LChV-LC5 sequence are shown; hyphens indicate identity to LChV-LC5. The groups that the isolates belong to are indicated at the left. Percent identities are summarized in Table 3.

Table 3. Summary of nucleotide sequence divergence in four amplified regions ${ }^{\mathrm{a}}$ of 31 British Columbia isolates of the LC5 isolate of Little cherry virus (LChV-LC5)

\begin{tabular}{|c|c|c|c|c|c|c|c|c|}
\hline \multirow[b]{2}{*}{ Group } & \multicolumn{2}{|c|}{ RdRp-1 (371 nt) ${ }^{b}$} & \multicolumn{2}{|c|}{ RdRp-2 (286 nt) } & \multicolumn{2}{|c|}{ HSP70 (564 nt) } & \multicolumn{2}{|c|}{ CPtr (232 nt) } \\
\hline & No. subst.c & \% diverg. ${ }^{\mathrm{d}}$ & No. subst. & $\%$ diverg. & No. subst. & $\%$ diverg. & No. subst. & $\%$ diverg. \\
\hline OK-1 & 0 & $0 \%$ & 0 & $0 \%$ & 0 & $0 \%$ & 0 & $0 \%$ \\
\hline OK-2 & 16 & $4.3 \%$ & 9 & $3.2 \%$ & 36 & $6.4 \%$ & 11 & $4.7 \%$ \\
\hline K-3 & $\mathrm{NA}^{\mathrm{e}}$ & NA & NA & NA & NA & NA & 10 & $4.3 \%$ \\
\hline K-4 & NA & NA & 41 & $14.3 \%$ & 111 & $19.7 \%$ & 40 & $17.2 \%$ \\
\hline K-5 & 8 & $2.2 \%$ & 5 & $1.8 \%$ & 33 & $5.9 \%$ & 6 & $2.6 \%$ \\
\hline K-6 & 6 & $1.6 \%$ & 3 & $1.1 \%$ & 8 & $1.4 \%$ & 2 & $0.9 \%$ \\
\hline
\end{tabular}

a Regions: RdRp = RNA dependent RNA polymerase; HSP70 = heat shock protein 70 homologue; $\mathrm{CP}=$ coat protein; $\mathrm{CPtr}=$ truncated coat protein region.

${ }^{\mathrm{b}}$ Indicates number of nucleotides of reverse transcriptase polymerase chain reaction (RT-PCR) product analyzed.

${ }^{\mathrm{c}}$ Refers to total number of conserved substitutions that occurred in each group of LChV-LC5 isolates compared to LChV-LC5.

${ }^{d}$ Refers to percentage of divergent residues (i.e., number of substitutions/total number of nucleotides compared $\times 100$ ).

e Sequence information not available due to negative RT-PCR reaction (see Table 2). 

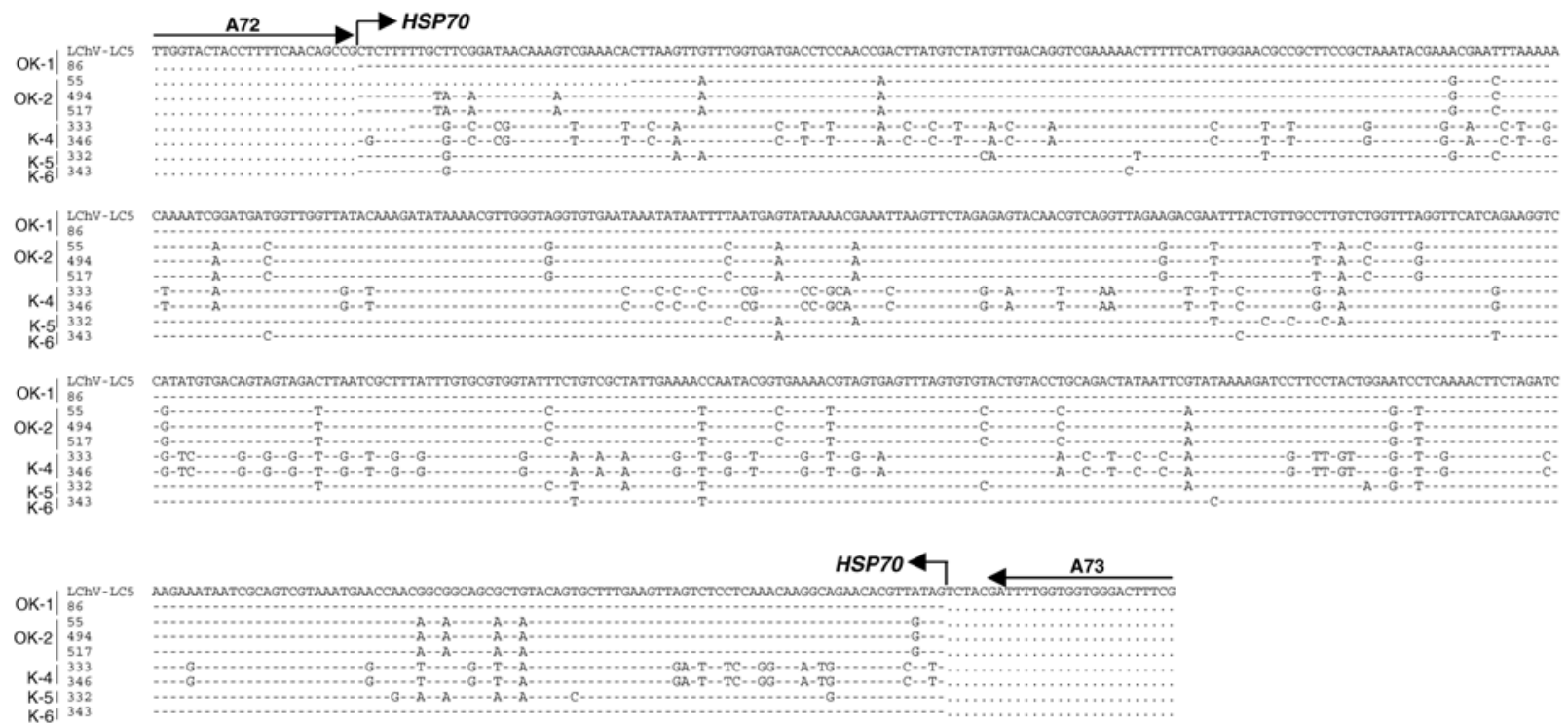

Fig. 3. Nucleotide sequence comparison of a portion of the heat shock protein 70 homologue (HSP70) open reading frame of several isolates of Little cherry virus LC5 (LChV-LC5). The sequence corresponds to a portion of the HSP70 region amplified by primers A72 and A73 (see Table 1). Locations of primers are indicated by forward and reverse arrows. A bent arrow shows the beginning of the region used in sequence comparisons. Dots correspond to regions for which sequence data were not obtained. Only nucleotides that differ from the LChV-LC5 sequence are shown; hyphens indicate identity to LChV-LC5. The groups that the isolates belong to are indicated at the left. Percent identities are summarized in Table 3.
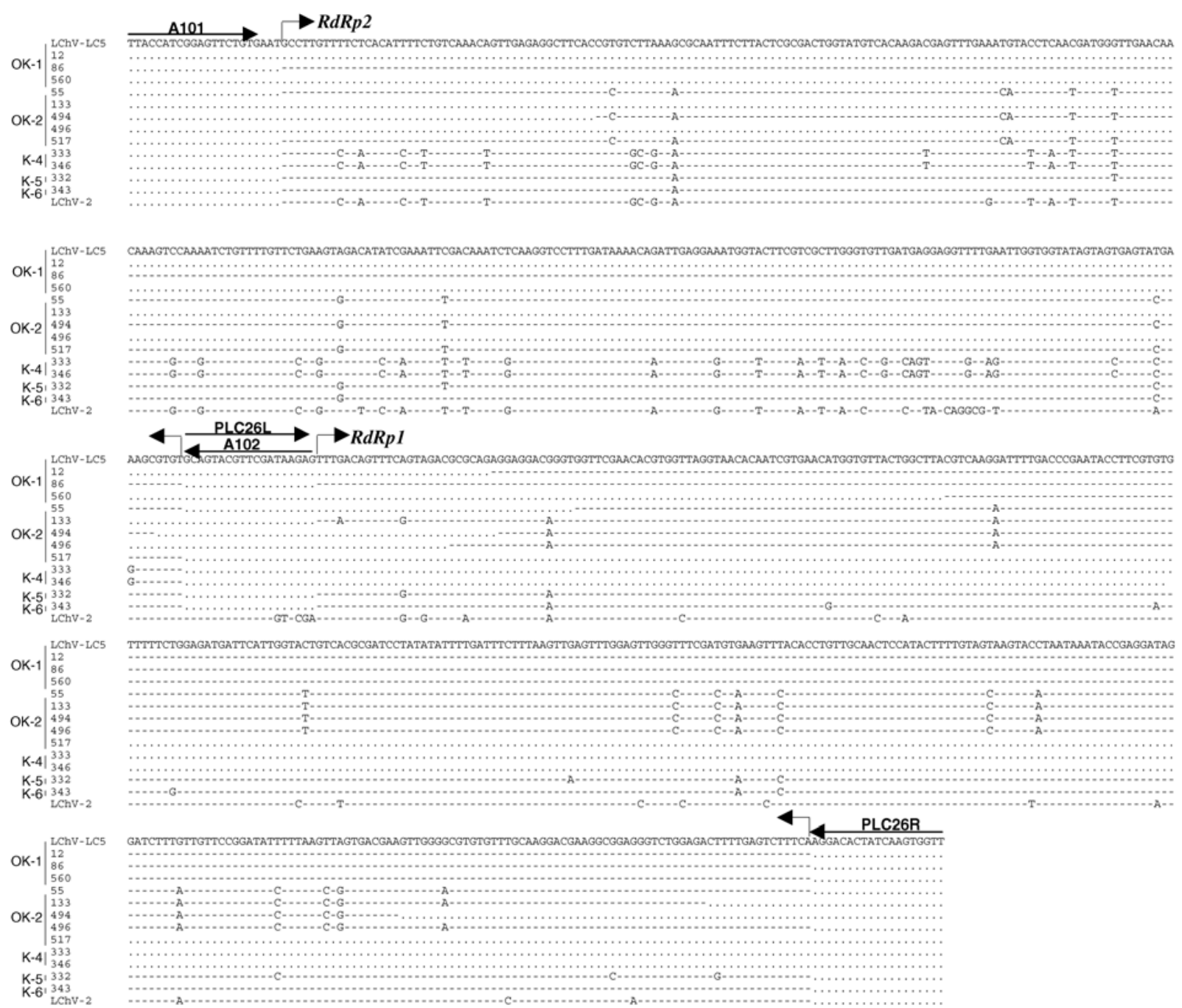

Fig. 4. Nucleotide sequence comparison of a portion of the RNA dependent RNA polymerase (RdRp) open reading frame of Little cherry virus-2 (LChV-2) and several British Columbia isolates of Little cherry virus LC5 (LChV-LC5). The sequence corresponds to the amplified RdRp1 and RdRp2 regions (see Table 1). Locations of primers are indicated by forward and reverse arrows. A bent arrow shows the beginning of the region used in sequence comparisons. Dots correspond to regions for which sequence data were not obtained. Only nucleotides that differ from the LChV-LC5 sequence are shown; hyphens indicate identity to LChV-LC5. The groups that the isolates belong to are indicated at the left. Percent identities are summarized in Table 3. 
a positive RT-PCR in the RdRp1 and CP regions (Table 2) (i.e., there was insufficient complementarity between primers and the viral RNA or cDNA to obtain annealing in

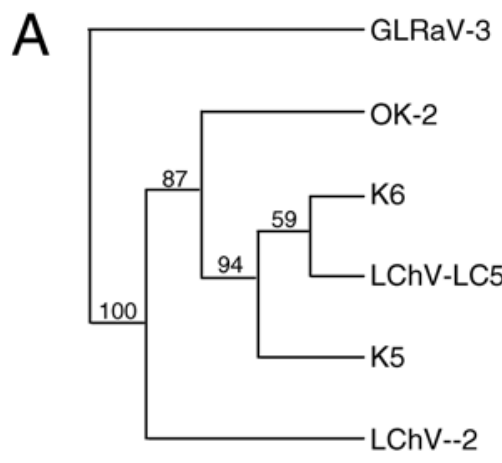

RdRp1

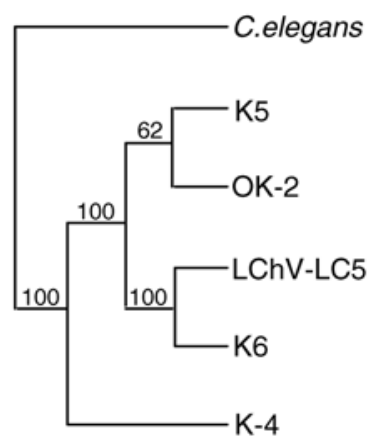

HSP70 the RT or PCR reactions). This may also explain the inability to obtain RT-PCR products for the RdRp1, RdRp2, HSP70, and $\mathrm{CP}$ regions of isolates of the members

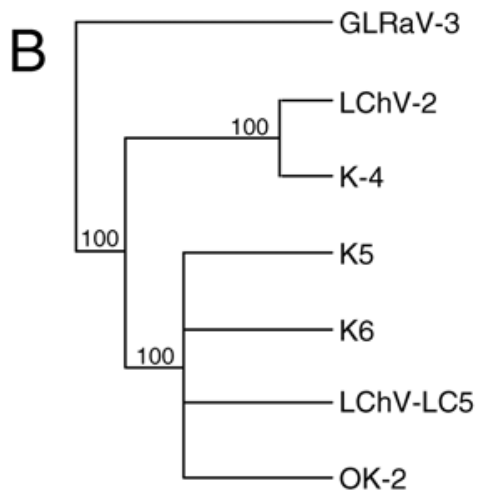

RdRp2

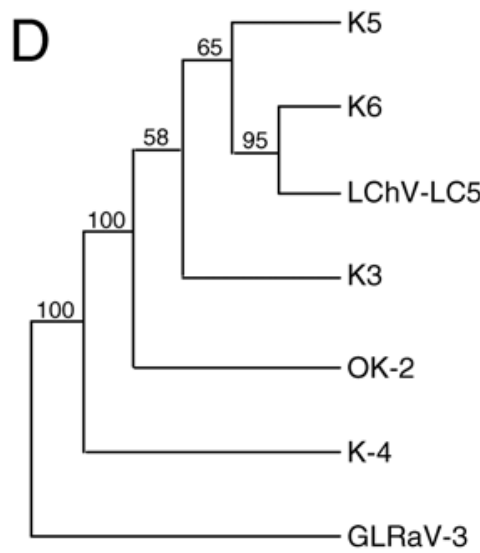

CPtr
Fig. 5. Dendrograms showing phylogenetic relationships among the RNA dependent RNA polymerase 1 (RdRp1), RdRp2, heat shock protein 70 homologue (HSP70), and truncated coat protein (CPtr) regions of the LC5 isolate of Little cherry virus (LChV-LC5). The numbers at the left indicate the number of times the group consisting of the species to the right of that fork occurred among the 100 dendrograms obtained following bootstrap analysis. Branches with a value of less than 58 are collapsed. Respective portions of the RdRp of Grapevine leafroll associated virus-3 (GLRaV-3) were used as the outgroup in $\mathbf{A}$ and $\mathbf{B}$ and the coat protein of GLRaV-3 (11) as the outgroup in D. A portion of the HSP70 of Caenorhabditis elegans was used as the outgroup in $\mathbf{C}$. of the K-3 group; however, in this case, the $\mathrm{CPtr}$ region is not nearly as diverged from LChV-LC5 as it is for group K-4.

Phylogenetic comparisons of the six major groups of LChV-LC5 isolates. Dendrograms based on nucleotide sequence comparisons of the four $\mathrm{LChV}$ LC5 regions analyzed (Fig. 5) show that K-6 (and to a lesser extent, K-5) is most closely related to LChV-LC5 (OK-1 group) and that K-4 (and to a lesser extent, OK-2) is the least closely related to LChV-LC5. The deduced phylogenetic relationships are in agreement with the overall level of divergence of these isolates in comparison to LChV-LC5 as determined in nucleotide sequence comparisons (Table 3 ).

The nucleotide sequences of an approximate $0.4-\mathrm{kb}$ portion of the $\mathrm{RdRp}$ (corresponding to part of RdRp1) of several LChV-LC5 isolates from British Columbia have recently been reported (3). Comparison of these sequences to those described here indicates that none of the isolates are identical to four different RdRp1 sequences described here (data not shown). This finding reinforces the conclusion that there is a high level of heterogeneity in LChV-LC5 isolates in British Columbia.

Comparison of British Columbia isolates of LChV-LC5 to LChV-2. Previous comparisons have shown that LChV-LC5 shares approximately $77 \%$ overall sequence identity with $\mathrm{LChV}-2$ in a $4.7-\mathrm{kb}$ region that comprises the HEL and RdRp regions (17). Portions of the nucleotide sequences of the RdRp1 and RdRp2 regions of members of the OK-1, OK-2, K-5, and $\mathrm{K}-6$ and the RdRp2 region of K-4 were compared to the corresponding regions of $\mathrm{LChV}-2$ to assess the level of sequence identity. Figure 4 shows that the RdRp2 region of the K-4 group shows the greatest level (94\%) of sequence identity to LChV-2. The remaining groups show approximately 85 to $86 \%$ identity to LChV-2 in this region. The dendrogram in Figure 5B further suggests a close relationship between $\mathrm{LChV}-2$ and the $\mathrm{K}-4$ group in the

Table 4. Amino acid sequence divergence between several regions ${ }^{\mathrm{a}}$ of the LC5 isolate of Little cherry virus (LChV-LC5) and the six major groups of LChVLC5 isolates ${ }^{\mathrm{b}}$

\begin{tabular}{|c|c|c|c|c|c|c|c|c|}
\hline \multirow[b]{2}{*}{ Group } & \multicolumn{2}{|c|}{$\operatorname{RdRp1}(123$ aa) } & \multicolumn{2}{|c|}{ RdRp2 (95 aa) } & \multicolumn{2}{|c|}{ HSP70 (187 aa) } & \multicolumn{2}{|c|}{ CPtr (77 aa) } \\
\hline & No. subst. ${ }^{d}$ & $\%^{\mathrm{e}}$ & No. subst. & $\%$ & No. subst. & $\%$ & No. subst. & $\%$ \\
\hline OK-1 & 0 & $0 \%$ & 0 & $0 \%$ & 0 & $0 \%$ & 0 & $0 \%$ \\
\hline OK-2 & 3 & $2.4 \%$ & 1 & $1.1 \%$ & 5 & $2.7 \%$ & 1 & $1.3 \%$ \\
\hline K-3 & $N A^{f}$ & NA & NA & NA & NA & NA & 1 & $1.3 \%$ \\
\hline K-4 & NA & NA & 3 & $3.2 \%$ & 14 & $7.5 \%$ & 7 & $9.1 \%$ \\
\hline K-5 & 0 & $0 \%$ & 0 & $0 \%$ & 3 & $1.6 \%$ & 0 & $0 \%$ \\
\hline K-6 & 1 & $0.8 \%$ & 0 & $0 \%$ & 1 & $0.5 \%$ & 0 & $0 \%$ \\
\hline
\end{tabular}

${ }^{a}$ Regions: RdRp = RNA dependent RNA polymerase; HSP70 = heat shock protein 70 homologue; $\mathrm{CP}=$ coat protein; $\mathrm{CPtr}=$ truncated coat protein region.

${ }^{\mathrm{b}}$ Comparisons are based on deduced amino acid sequences obtained from composite nucleotide sequences of the six LChV-LC5 groups compared in Figures 2,3 , and 4 .

${ }^{c}$ Number of amino acids is in parentheses following name of region analyzed.

${ }^{\mathrm{d}}$ Refers to number of amino acid substitutions.

${ }^{e}$ Refers to percentage of diverged residues in comparison to LChV-LC5.

${ }^{\mathrm{f}}$ Sequence information not available due to negative reverse transcriptase polymerase chain reaction (see Table 2). 
RdRp2 region. The K-4 RdRp1 region could not be amplified using the RdRp1 primer set (Table 2), so sequence identity to $\mathrm{LChV}-2$ in this region could not be determined.

Amino acid sequence comparisons. Table 4 summarizes amino acid sequence divergence between LChV-LC5 (OK-1 group) and representative members of the five other groups of isolates. Levels of divergence range from 0 to $9.1 \%$, and the relative levels of sequence identity between LChV-LC5 and the other isolates generally reflected the levels of nucleotide sequence divergence shown in Table 3 . The highest level of amino acid sequence divergence from LChV-LC5 occurred in the $\mathrm{CPtr}$ region of $\mathrm{K}-4$, where substitutions in seven out of 77 compared amino acid positions were found (9.1\% divergence).

Detection of LChV-LC5 in British Columbia. The isolates used in this study were identified in orchards in British Columbia using a recently developed ELISA based on antibodies made to the coat protein of LChV-LC5 (17). ELISA is therefore capable of detecting variants with up to $17.2 \%$ nucleotide sequence divergence in the CPtr and up to $19.7 \%$ nucleotide sequence divergence elsewhere in the genome (Table 2). Given the high variability of LChV-LC5 sequences in British Columbia that we describe here, ELISA is likely to be more useful than RT-PCR for detecting infected trees since small changes in nucleotide sequence can adversely affect efficiency of oligonucleotide primer binding. This is reinforced by our observation that isolates K-3 and K-4, which are readily detected by ELISA using LChV-LC5 coat protein antiserum, could not be detected by a previously developed RT-PCR using primers PLC26L and PLC26R (Table 1) (3).

Since LChV-LC5 shows a high capacity for variation, it is also possible that some isolates of LChV-LC5 may escape detection by ELISA. In our initial surveys for LChV-LC5 infection in British Columbia, it was found that some trees displaying LChD symptoms did not react in ELISA using LChV-LC5 antibodies (J. Theilmann and D. Rochon, unpublished observations). It was subsequently found that sev- eral of these samples contained a variant of LChV-1 (1). This confirmed the previous findings of Rott and Jelkmann (14) that LChV-1 occurs in Canada. The inability of LChV-LC5 antibodies to react to LChV-1 isolates is not surprising given the great level of divergence in the coat proteins of these two viruses (17).

We currently do not know if LChV-LC5 antibodies can detect the $\mathrm{LChV}-2$ isolate originally described by Rott and Jelkmann (14). However, it is likely that these antibodies would detect the more recently described LChV-2(USA6b) due to the much higher level of sequence identity of this virus to LChV-LC5 (15). However, any conclusions regarding reactivity of LChV-LC5 antibodies awaits direct experimental testing.

In summary, this study shows that a high level of sequence variation exists in LChVLC5 isolates in British Columbia. The existence of this high level of variation should be considered in the selection of methods used for diagnosis during surveys for this virus.

\section{ACKNOWLEDGMENTS}

This work was partially supported by the Okanagan/Kootenay Cherry Growers Association and by Agriculture and Agri-Food Canada Matching Investment Funds. We thank Gayle Jespersen (British Columbia Ministry of Agriculture, Food and Fisheries) for collecting cherry leaf samples. We are grateful to David Theilmann for critically reviewing this manuscript prior to submission.

\section{LITERATURE CITED}

1. Bernardy, M. G., French, C. J. Milks, M., and Jesperson, G. 2002. New variant of Little cherry virus associated with little cherry disease of sweet cherry in British Columbia, Canada. Plant Dis. 86:1406.

2. Eastwell, K. C., and Bernardy, M. G. 1996. Association of high molecular weight doublestranded RNA with little cherry disease. Can. J. Plant Pathol. 18:203-208.

3. Eastwell, K. C., and Bernardy, M. G. 2001. Partial characterization of a closterovirus associated with apple mealybug-transmitted little cherry disease in North America. Phytopathology 91:268-273.

4. Eastwell, K. C., and Li, T. S. C. 1994. Status of the little cherry disease eradication program in the Kootenay Valley of British Columbia. Can. Plant Dis. Surv. 74:115-116.

5. Felsenstein, J. 1985. Confidence limits on phylogenies: An approach using the Bootstrap. Evolution 39:783-791.

6. Fitch, W. M., and Margoliash, E. 1967. Con- struction of phylogenetic trees. Science 155:270-284.

7. Foster, W. R., and Lott, T. B. 1947. "Little cherry", a virus disease. Sci. Agric. 27:1-6.

8. Jelkmann, W., Fechter, B., and Agranovsky, A. A. 1997. Complete genome structure and phylogenetic analysis of little cherry virus, a mealybug-transmissible closterovirus. J. Gen. Virol. 78:2067-2071.

9. Jespersen, G. D., and Carter, G. 1994. Little cherry virus survey in the Okanagan Valley of British Columbia. Can. Plant Dis. Surv. 74:117.

10. Karasev, A. V. 2000. Genetic diversity and evolution of closteroviruses. Annu. Rev. Phytopathol. 38:293-324.

11. Ling, K. S., Zhu, H. Y., Drong, R. F., Slightom, J. L., McFerson, J. R., and Gonsalves, D. 1998. Nucleotide sequence of the $3^{\prime}$-terminal two-thirds of the grapevine leafroll-associated virus-3 genome reveals a typical monopartite closterovirus. J. Gen. Virol. 79:1299-1307.

12. Raine, J., McMullen, R. D., and Forbes, A. R. 1986. Transmission of the agent causing little cherry disease by apply mealybug Phenacoccus aceris and the dodder Cuscuta lupuliformis. Can. J. Plant Pathol. 8:6-11.

13. Rochon, D. M., Theilmann, J., and Jesperson, G. 2000. Little cherry virus survey in the Okanagan and Kootenay Valleys of British Columbia. Can. Plant Dis. Surv. 81:51.

14. Rott, M. E., and Jelkmann, W. 2001. Detection and partial characterization of a second closterovirus associated with little cherry disease, Little cherry virus-2. Phytopathology 91:261267.

15. Rott, M. E., and Jelkmann, W. 2002. Little cherry closterovirus - occurrence of LChV-1 and 2, complete genomic characterization of LChV-2 and its relation to the proposed LChV3 , isolated from Canada. Page 444 in: Proc. XII Int. Congr. Virol.

16. Slykhuis, J. T., Yorston, J., Raine, J. McMullen, R. D., and Li, T. S. C. 1980. Current status of little cherry disease in British Columbia. Can. Plant Dis. Surv. 60:37-42.

17. Theilmann, J., Mozafari, J., Reade, R., Wu, Z., Xie, W., Jesperson, G., Bernardy, M., Eastwell, K. C., and Rochon, D. 2002. Partial nucleotide sequence and genome organization of a Canadian isolate of Little cherry virus and development of an enzyme-linked immunosorbent assay-based diagnostic test. Phytopathology 92:87-98.

18. Welsh, M. F., and Cheney, P. W. 1976. Little cherry. Pages 231-237 in: Viruse Diseases and Noninfectious Disorders of Stone Fruits in North America. R. M. Gilmer, J. D. Moore, G. Nyland, M. F. Welsh, and T. S. Pine, eds. U.S. Dep. Agric. Agric. Res. Serv.

19. Yorston, J. M., McMullen, R. D., Slykhuis, J. T., and Welsh, M. F. 1981. Little Cherry Disease in British Columbia. Province of British Columbia Ministry of Agriculture and Food, Victoria, B.C. 